\title{
Virus associated with thickening of the cladodes of prickly pear (Opuntia ficus-indica Mill.)
}

\author{
Alba Suaste-Dzul ${ }^{1}$, Reyna Isabel Rojas-Martínez ${ }^{1^{*}}$, Daniel Ochoa-Martínez ${ }^{1}$, Emma \\ Zavaleta-Mejía ${ }^{1}$, Daisy Pérez-Brito ${ }^{2}$, Camilo Hernández-Juárez ${ }^{3}$ and Douglas Rodríguez- \\ Martínez ${ }^{4}$
}

${ }^{1}$ Colegio de Postgraduados, Campus Montecillo, Instituto de Fitosanidad-Fitopatología, Montecillo, Estado de México 56230, México. ${ }^{2}$ Centro de Investigación Científica de Yucatán, A. C. Chuburná de Hidalgo. Mérida, Yucatán 97200, México. ${ }^{3}$ Universidad Autónoma de Chapingo, Parasitología Agrícola, Chapingo, Estado de México 56230, México. ${ }^{4}$ Colegio de Postgraduados, Campus Montecillo, Biotecnología de Semillas, Montecillo, Estado de México 56230, México.

\begin{abstract}
Symptoms putative to phytoplasmas and virus as yellowing, mosaic, proliferation and deformation of fruits and thickening of the cladodes of prickly pear have been observed in Nopaltepec, Estado de México. The objective of this investigation was to detect the presence of virus in samples of prickly pear showing thickening syndrome of the cladodes. The analysis of double-stranded RNA in prickly pear tissue whit the symptoms mentioned above revealed the presence of viral RNA. In symptomatic tissue, flexible rods of 950-1700 $\mathrm{nm}$ in length were observed with the aid of transmission electron microscopy. The virus was transmitted mechanically to Nicotiana tabacum var. Xanthi, N. glutinosa, N. occidentalis, N. benthamiana, Chenopodium quinoa, C. amaranticolor and Datura stramonium. Results from RT-PCR indicate that the particle does not correspond to TMV, neither to member of the Potyviridae family or species of the genus Potexvirus.
\end{abstract}

Key-words: dsRNA, long flexible particles, transmission electron microscopy

\section{INTRODUCTION}

Opuntia ficus-indica is the cactus of greatest economic importance in the world, been grown in Europe, the Middle East, Africa, Asia, Oceania and America (Barbera, 1995). The fruits of prickly pear are greatly appreciated in countries such as Argentina, United States (Curtis, 1977), Chile (Sudzuki et al., 1993), Israel (Nerd and Mizrahi, 1993) and South Africa (Wessels, 1988). Mexico is the principal producer, with an annual production of 744,250 tons from the Puebla, Distrito Federal, Baja California, Zacatecas and Aguascalientes states (SIAP, 2009).

Several diseases affect this crop, mainly phytopathogenic fungi (such as Alternaria sp. and Macrophomina sp.) and bacteria (Borrego and Burgos, 1986). In recent years increasing numbers of plants showing symptoms characterized by thickening of the cladodes, mosaic, yellowing; and proliferation and deformation of the fruits. Because of the symptomatology it was suspected that a virus was involved.
Felker et al. (2009) report that in California the thickening of the cladodes is caused by Tobacco bushy top virus, and suggest that the symptoms found in Italy, South Africa and Mexico are induced by this same virus. On the other hand, Lastra et al. (1976) reported a sickness affecting Nopalea cochenillifera L., with symptoms of a light speckling in the young shoots, and the results from transmission in indicator plants, electron microscopy and serological tests indicated that they were dealing with Cactus virus $X$. So far, several species of virus have being found affecting cultivated cacti, such as Sammons's opuntia virus (SOV), Cactus virus X (CVX), Zygocactus virus $X$ (ZVX), Saguaro cactus virus (SCV) and Tomato spotted wilt virus (TSWV) (Giri and Chessin, 1975; Lastra et al., 1976; Attothom et al., 1978; Milbrath and Nelson, 1972; Hausbeck and Gildow, 1991).

Based on the above, the objective of the present investigation was to identify a possible viral etiology associated with the syndrome of

*Author for correspondence: rojas@colpos.mx 
thickening and mosaic of the cladodes by means of analysis of double-stranded RNA, mechanicaltransmission to indicator plants, electron microscopy and RT-PCR.

\section{MATERIAL AND METHODS \\ Plant material}

Thirty-five cladodes of prickly pear showing symptoms of thickening, yellowing, mosaic, proliferation and deformation of fruits (Figure 1) were collected in the municipality of Nopaltepec, in the Estado de México. After dipping the cladodes in Radix $10,000^{\circledR}$ (indole-3-butyric acid $10,000 \mathrm{ppm}$ ) to encourage rooting, were placed in containers with sterile soil, in order to provide a source of inoculum.

\section{Inoculation of indicator plants}

Portions of epidermis of $2 \mathrm{~cm}^{2}$ were separated from cladodes with symptoms of thickening and mosaic using a scalpel and dissection tweezers. They were macerated with mortar and pestle in $0.01 \mathrm{M}$ phosphate buffer of $\mathrm{pH}$ 7.0. The macerate was rubbed with a cotton mop onto four young leaves previously dusted with carborundum 600 grade of the following indicator plants: Nicotiana tabacum var. Xanthi, N. glutinosa, $N$. clevelandii, $N$. occidentalis, $N$. rustica, $N$. benthamiana, Datura stramonium, Chenopodium quinoa and $C$. amaranticolor. Control plants were treated only with phosphate buffer solution.

Plants remained in a glasshouse at $20-30^{\circ} \mathrm{C}$ for 45 days and every 72 hours the symptoms were recorded. The test with indicator plants was repeated once. Plants showing localized necrotic lesions, chlorosis and mosaic were used as inoculum sources for mechanical transmission to healthy indicator plants, and thus confirm the development of the same symptoms caused by a single phytopathogenic virus.

\section{Electron microscopy}

From the 35 samples of symptomatic cladodes a partial purification of the virus particles was achieved according to the protocol reported by Lastra et al. (1976). The extractions partially purified were subjected to negative staining with uranyl acetate $2 \%, \mathrm{pH}$ 6.8. Observation, measurements and microphotography were carried out in a Model JEOL JEM 1200 EX II transmission electron microscope at $60 \mathrm{kV}$ (Colariccio et al., 1996).

\section{Isolation of double-stranded RNA (dsRNA)}

The protocol of Dodds et al. (1984) was used for the extraction of viral double-stranded RNA, from cladodes of prickly pear showing typical symptoms of thickening, mosaic and deformation of fruits, and from mechanically inoculated indicator plants that showed necrotic local lesions, chlorosis and mosaics. To confirm that we were dealing with double-stranded viral RNA, each extraction was digested with DNAse I and nuclease S1 (Promega, Madison, WI, USA), using $10 \mu \mathrm{g} / \mathrm{mL}$ for $1 \mathrm{~h}$ at $37^{\circ} \mathrm{C}$, according to the conditions indicated by the supplier.

Viral dsRNA was analyzed using polyacrylamide gel $(6 \% \mathrm{w} / \mathrm{v})$ electrophoresis in TBE (Tris-borateEDTA) $1 \mathrm{X}$ buffer, run for $1.5 \mathrm{~h}$ at $100 \mathrm{~V}$, with 100 bp molecular markers $\left(\right.$ Invitrogen ${ }^{\circledR}$ ). Gels were stained with silver nitrate.
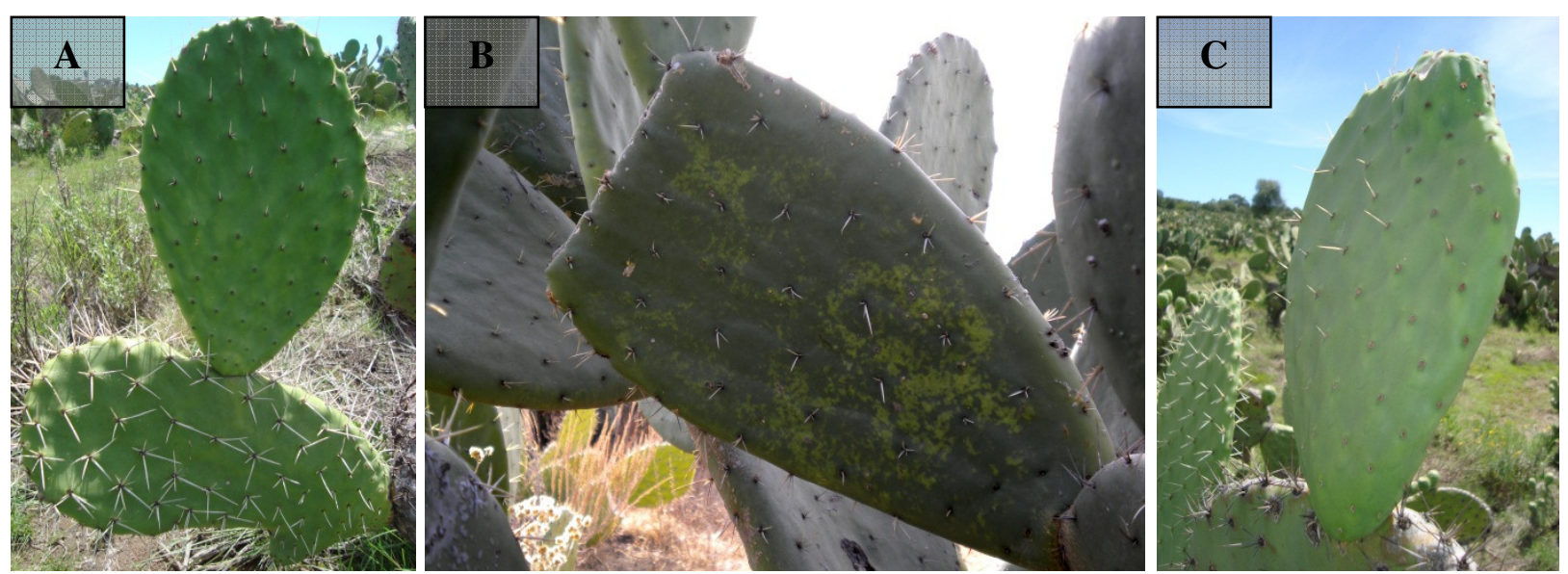

Figure 1- Symptoms of Mosaic (A), chlorotic spots (B) and thickening and mosaic (C) on the cladode and fruit of prickly pear, collected from Nopaltepec, Mexico State. 


\section{Extraction of total RNA}

Total RNA was isolated from foliar tissue of the infected indicator plants using RNeasy ${ }^{\circledR}$ Mini Kit (QIAGEN, Mexico-DF, Mexico). This RNA was used to detect the presence of TMV, members of Potyviridae and species of genera Potexvirus. As positive controls was used RNA from Solanum lycopersicum mechanically inoculated with TMV (Tobacco mosaic virus), lyophilized tissue of potato infected with PVY (Potato virus $Y$ ) and lyophilized tissue of papaya infected with PapMV (Papaya mosaic virus), respectively.

\section{RT-PCR}

For the synthesis of cDNA, to a PCR tube was added $2 \mu \mathrm{g}$ de RNA and $10 \mu \mathrm{g}$ of the primer specific for the TMV, Potyvirus and Potexvirus groups (Table 1). The mixture was incubated at $72^{\circ} \mathrm{C}$ for $10 \mathrm{~min}$ and then transferred to ice. Subsequently, mixtured with 5X M-MLV buffer (Promega $^{\circledR}$, Madison-WI, USA) 0.1M DTT, $200 \mu \mathrm{M}$ dNTPs and $1 \mathrm{U}$ of the M-MLV reverse transcriptase $(10,000 \mathrm{U})$ (Promega ${ }^{\circledR}$, Madison-WI, USA). The mixture was incubated at $37^{\circ} \mathrm{C}$ for 60 min, following a cycle of $10 \mathrm{~min}$ at $70^{\circ} \mathrm{C}$.
For the PCR a initial denaturation at $94^{\circ} \mathrm{C}$ for 5 min, followed by 31 cycles of $2 \mathrm{~min}$ at $95^{\circ} \mathrm{C}, 2$ min at temperature of aneling (Table 1) and $2 \mathrm{~min}$ at $72^{\circ} \mathrm{C}$, with a final extension of $5 \mathrm{~min}$ at $72^{\circ} \mathrm{C}$ was used for each virus group.

In all cases, a final volume of $25 \mu \mathrm{L}$ of reaction mixture was used with the following reagents: PCR buffer $1 \times(10 \times, 20 \mathrm{mM}$ tris- $\mathrm{HCl}, 500 \mathrm{mM}$ $\mathrm{KCl}, \mathrm{pH}$ 8.4) (Biogénica ${ }^{\circledR}$, Mexico-DF, Mexico),

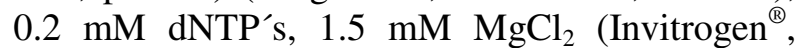
Mexico-DF, Mexico), 10 pmol of each primer, $1 \mathrm{U}$ of Taq DNA polymerase (Biogénica ${ }^{\circledR}$, Mexico-DF, Mexico) and $1 \mu \mathrm{g}$ of template cDNA.

The amplification products obtained were visualized using agarose (Invitrogen ${ }^{\circledR}$, Mexico-DF, Mexico) al $1.5 \%(\mathrm{w} / \mathrm{v})$ gel electrophoresis in TAE buffer $1 \times$ (Tris-acetate- EDTA) at $100 \mathrm{~V}$ for 50 min, with ethylene bromide stain incorporated. A molecular marker of $100 \mathrm{bp}$ was used. The gels were visualized in a UV transilluminator (Gel Doc 2000, Bio-Rad $\left.{ }^{\circledR}\right)$ and the images were captured and analyzed with the program Quantity One 4.1.1.

Table 1. Primers, anneling temperature and length of RT-PCR product for each viru's group.

\begin{tabular}{llccc}
\hline \multicolumn{1}{c}{ Primers (5'-3') } & TA & product & \multicolumn{1}{c}{ Authors } \\
\hline TMV & F:GCIYTIGGIAAYCARTTYCARACICARCA & $56{ }^{\circ} \mathrm{C}$ & $250 \mathrm{pb}$ & Torre et al., 2007 \\
& R:IGCRTCIARIGTYCIGCIGTIGTIGGRTT & & & \\
Potyviridae & F:GTTTTCCCAGTCACGAC & $47{ }^{\circ} \mathrm{C}$ & $1,700 \mathrm{pb}$ & Chen et al., 2001 \\
& R:GTTTTCCCAGTCACGAC(T) $)_{15}$ & & & \\
Potexvirus & F:AGCATRGCNSCRTCYTG & $51{ }^{\circ} \mathrm{C}$ & $600 \mathrm{pb}$ & $\begin{array}{l}\text { Van der Vlugt and } \\
\text { R:TCAGTRTTDGCRTCRAARGT }\end{array}$ \\
& & & Berendsen, 2002 \\
\hline
\end{tabular}

TA: anneling temperature, $\mathrm{F}$ : forward, R: reverse.

\section{RESULTS}

The indicator plant species inoculated mechanically with the macerates of the epidermis from cladodes of prickly pear with the syndrome of thickening and mosaic, showed symptoms between 6 and 21 days after inoculation.

The symptoms observed in the indicator plants were local necrotic lesions in Nicotiana tabacum var. Xanthi, N. glutinosa and Datura stramonium, in Chenopodium quinoa, C. amaranticolor and $N$. occidentalis they produced local chlorotic lesions and uniquely in $N$. benthamiana, a mosaic in the inoculated leaves and in new leaves, which indicated systemic movement of the virus in this plant (Figure 2). No symptoms were observed in $N$. clevelandii and $N$. rustica. 


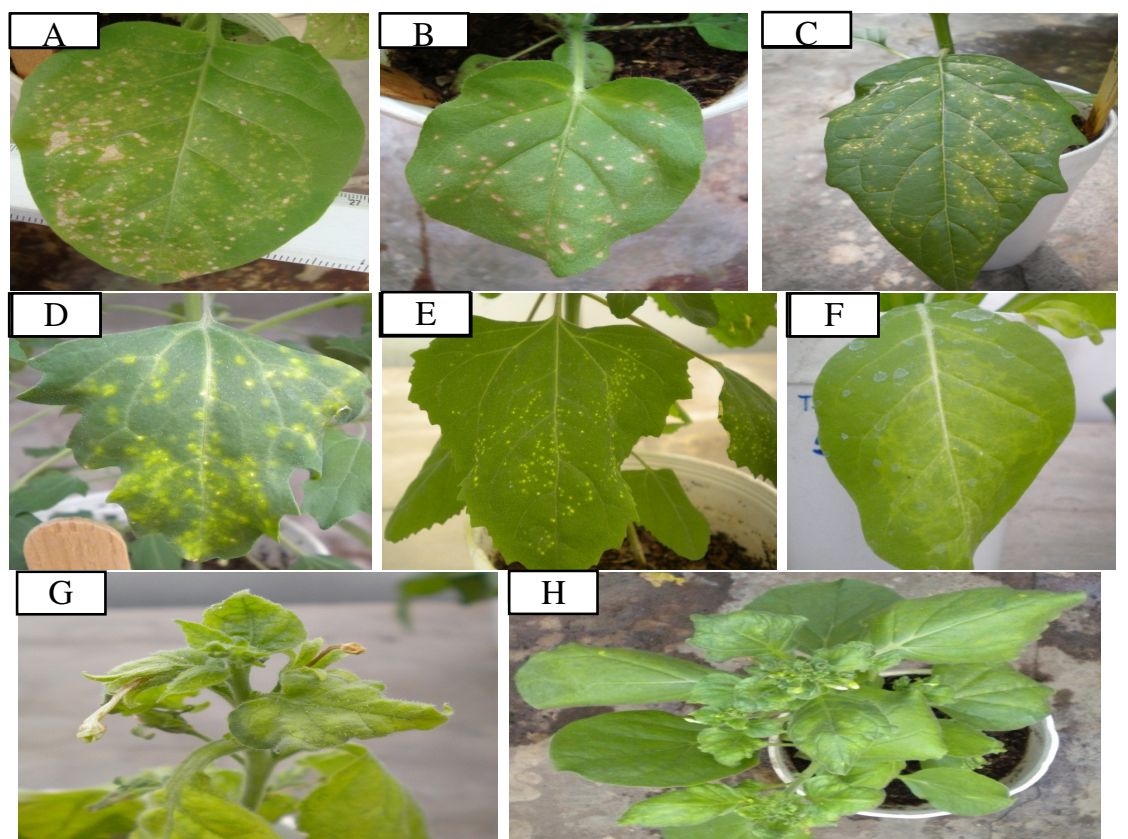

Figure 2- Symptoms observed in plants inoculated mechanically whit the macerated skin of prickly pear. A) Annular local lesions in Nicotiana tabacum var. Xanthi, B) local necrotic lesions in N. glutinosa and C) Datura stramonium. D) Local lesions chlorotic in Chenopodium quinoa, E) C. amaranticolor, and F) N. occidentalis, G) and $\mathbf{H})$ mosaic on $N$. benthamiana.

The symptoms observed in the indicator plants following the inoculation of tissue samples from cladodes of prickly pear confirmed the presence of a single virus associated with the thickening and mosaic observed in the cladodes, since all of the tests of mechanical inoculation revealed the same pattern of symptoms. In the preparations made from the partial purification of virus from prickly pear showing thickening of the cladodes, virus particles in the form of flexible rods, with a mean length of 950-1700 nm, were observed (Figure 3).

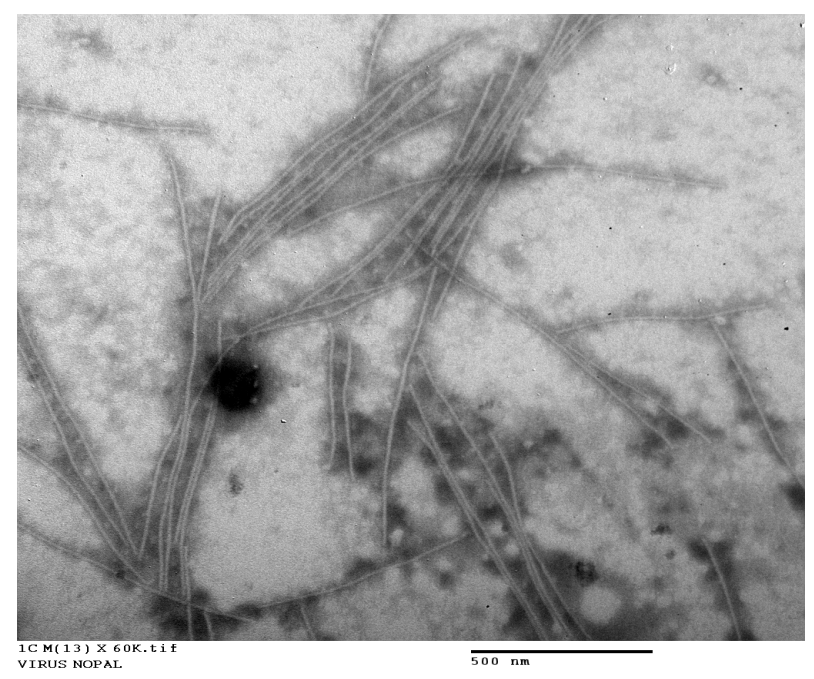

Figure 3- Viral particles in the form of flexible rod (950-1700 nm) of virus associated with symptoms of thickening and mosaic cladode prickly pear.

The electrophoretic pattern of the dsRNA digested with DNAse I and Nuclease showed three bands of 6,000 bp, 1,500 bp and 600 bp (Fig. 4). On the other hand, the total RNA obtained from each sample indicator plants was of good quality and integrity with a concentration of $631.1 \mathrm{ng} / \mu \mathrm{L}$ and levels of purity of 1.69 and 1.96 (Figure 5A). The results of the verification of the stability of the cDNA with the amplification for the endogenous gene for glyceraldehyde 3-phosphate dehydrogenase (GAPDH), was obtained a fragment of approximately $217 \mathrm{bp}$ for the samples and for the positive controls (data not showing).

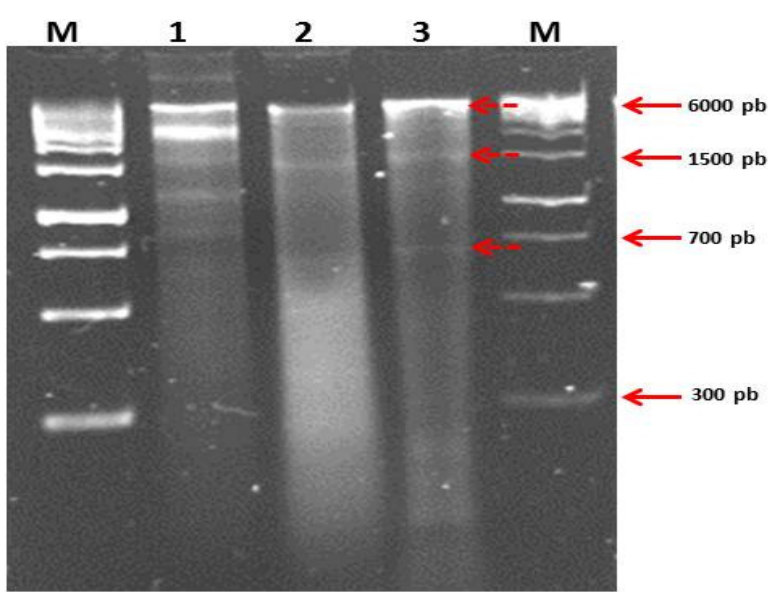


Figure 4- Electrophoretic pattern dsRNA obtained from Nicotiana benthamiana inoculated with epidermis prickly pear whit mosaic and thickening of the cladode. Line M) molecular marker $1 \mathrm{~kb}, 1)$ dsRNA without enzymatic digestion, 2) dsRNA treated with DNase I $\left(\right.$ Roche $\left.^{\circledR}\right)$, 3) dsRNA treated with S1 nuclease $\left(\right.$ Promega $\left.{ }^{\circledR}\right)$.
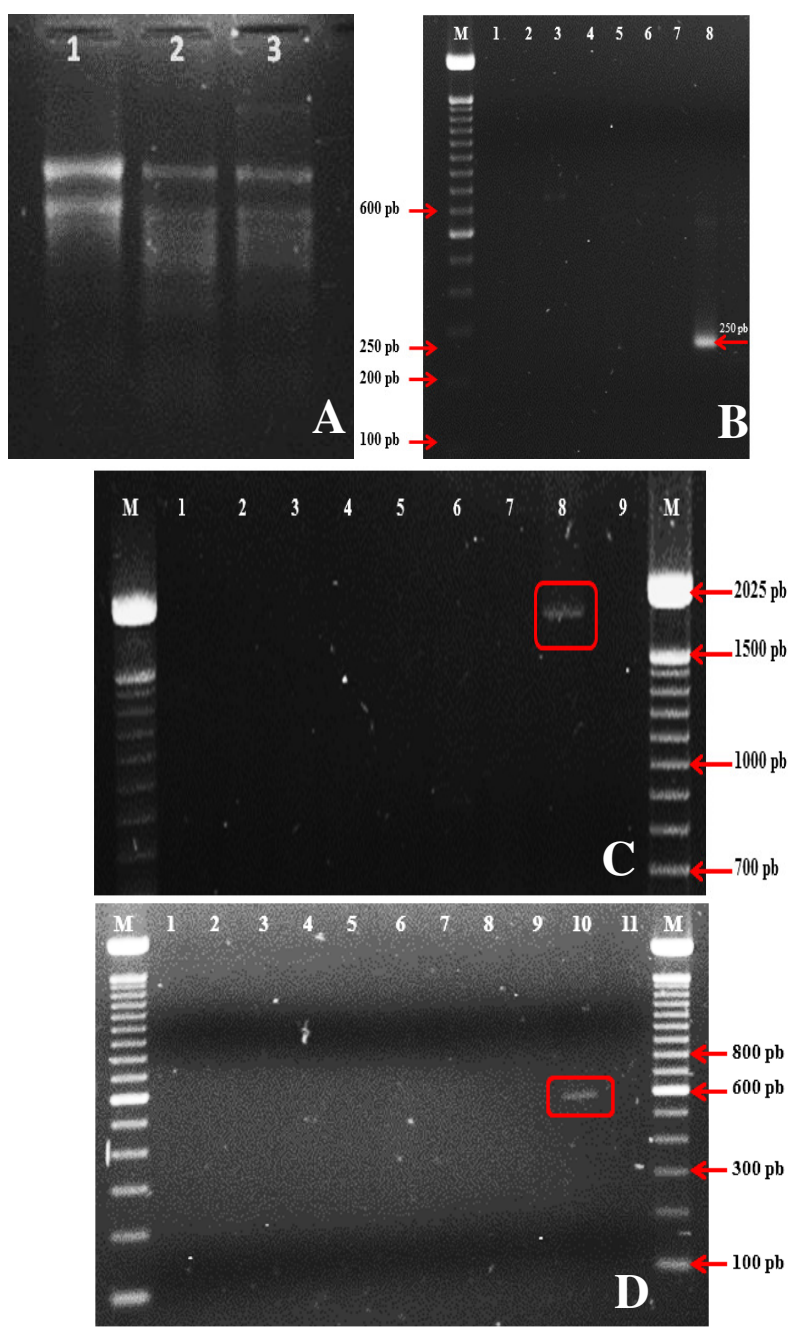

Figure 5- A. Electrophoresis of total RNA obtained from indicator plants inoculated with cladode of prickly pear with symptoms of mosaic and thickening of the cladode: Line 1) Chenopodium quinoa, 2) $C$. amaranticolor, 3) Nicotiana benthamiana. B. PCR product obtained with oligonucleotides specific for TMV: M) molecular marker $100 \mathrm{bp}$, 1) Nicotiana tabacum var. Xanthi, 2) N. glutinosa, 3) Chenopodium quinoa, 4) N. occidentalis, 5) N. benthamiana, 6) Datura stramonium, 7) C. amaranticolor, 8) positive control Tobacco mosaic virus. C. PCR product obtained with primers for members of the family Potyviridae: M) molecular marker $100 \mathrm{bp}$, 1) Nicotiana tabacum var. Xanthi, 2) N. glutinosa, 3) Chenopodium quinoa, 4) $N$. occidentalis, 5) N. benthamiana, 6) Datura stramonium, 7) C. amaranticolor, 8) positive control
Potato virus $Y$; 9) negative control. D. PCR product obtained with oligonucleotides for Potexvirus: M) molecular marker $100 \mathrm{bp}$; 1) Nicotiana tabacum var. Xanthi, 2) N. glutinosa, 3) Chenopodium quinoa, 4) $N$. occidentalis, 5) N. benthamiana, 6) Datura stramonium, 7) C. amaranticolor, 8) Chenopodium quinoa repetition, 9) $N$. benthamiana repetition, 10) positive control Papaya mosaic virus, 11) negative control.

The expected amplification product for TMV of $250 \mathrm{bp}$ was not observed in the samples analyzed, only in the positive control Solanum lycopersicum (Fig. 5B). In the case of analysis for members of the family Potyviridae, only obtained a amplification to $1,700 \mathrm{pb}$ for positive control corresponding to a Potato virus $Y$, while for the problem samples were negative (Fig. 5C). In a similar manner, in the test for detection of species of Potexvirus, there was only amplification of the fragment $600 \mathrm{bp}$ for the PapMV (positive control), but not in the problem samples (Fig. 5D).

\section{DISCUSSION}

The symptoms obtained from mechanical transmission tests with indicator plants inoculated with tissue from cladodes showing thickening and mosaic established that we were not dealing with TMV, since this induces local lesions and systemic mosaic in Nicotiana tabacum var. Xanthi (Astier et al., 2006; Himmel, 2003); in our study we only obtained local necrotic annular lesions.

De la Torre et al. (2007) reported the presence of a variant of TMV in prickly pear, causing local necrotic lesions in Nicotiana benthamiana and $N$. rustica, light mosaic in inoculated leaves of $N$. tabacum var. White Burley and Capsicum annuum, and no symptoms in Chenopodium quinoa. These results differ from those obtained in the present study, specifically in $N$. benthamiana, in which we observed mosaic, the local chlorotic lesions in Chenopodium quinoa, the absence of symptoms in $N$. rustica, and the unique annular local lesions in Nicotiana tabacum var. Xanthi.

The family Potyviridae contains the greatest number of virus species that infect plants (Kraus et al., 2010), constituting from the economic point of view the most important group of plant viruses (Zerbini and Zambolim, 1999). Amongst the indicator plant species that react with various members of the genus Potyvirus are Chenopodium quinoa and $C$. amaranticolor, which show local necrotic lesions and Capsicum annuum with an 
initial necrosis followed by systemic symptoms in the leaves (Valenzuela et al., 2003). There are reports that a virus of the genus Potexvirus, which includes various species infecting prickly pear such as Cactus virus $X$ (CXV), causes local chlorotic lesions in $C$. quinoa and $C$. amaranticolor but no symptoms in Datura stramonium and Nicotiana glutinosa (Lastra et al., 1976). Another potexvirus, is Zygocactus virus $X$ (ZXV), which causes systemic mosaic in Atriplex hastata and local necrotic lesions and systemic mosaic in Chenopodium quinoa (Brunt et al., 1996). Therefore, the results obtained in the present study indicate that the virus associated with thickening of the cladodes in prickly pear is neither a genus from the family Potyviridae nor a species of the genus Potexvirus.

Other microscopy studies indicate that the tobamoviruses have particles with rigid cylinders of $300 \mathrm{~nm}$ in length and $18 \mathrm{~nm}$ in diameter, whilst potyviruses have particles that are flexible filaments with dimensions of $680 \mathrm{~nm}-900 \mathrm{~nm}$ in length and 11-15 $\mathrm{nm}$ in diameter (ICTV, 2005). All of the potexviruses are morphologically similar, with flexed filaments measuring 470 to $580 \mathrm{~nm}$ in length and $13 \mathrm{~nm}$ in diameter (ICTV, 2005; AbouHaidar et al., 1998). The morphology of viral particle isolated from purified partial cladode of prickly pear is similar to those reported for the genera Potyvirus and Potexvirus (Conti et al., 2001), although the lengths are less than those we measured under the microscope. Despite this, and the fact that it has not yet been reported from Mexico, we applied molecular tests to our samples for members of the genus Potexvirus, to which Cactus virus $X$ belongs. The viral particles obtained from cladodes of prickly pear showing symptoms of thickening and mosaic were in the form of flexible filaments of 900-1700 nm in length. Based on the differences in morphology and length of the viral particle observed under the electron microscope, the virus under study is different to TMV, genera of the family Potyviridae and species of Potexvirus with which they were compared. The double-stranded RNAs of various members of tobamovirus, potyvirus y potexvirus are described and compared in a study by Valverde et al. (1986) for the evaluation of their potential use in the diagnosis of these viruses. In plants infected with tobamovirus (TMV-type and TMV-U5) a band of dsRNA of high molecular weight $\left(4.3 \times 10^{6} \mathrm{D}\right)$ and two bands in common. with greater mobility of $2.1 \times 10^{6}$ and $0.42 \times 10^{6} \mathrm{D}$ were detected; for various members of the genus Potyvirus (one of which was Potato virus $Y$ ), a band of $6.5 \times 10^{6}$ was obtained; in addition, similar patterns of dsRNA in the potexviruses examined (Potato virus $X$ and Cactus virus $X$ ) provided evidence of a pattern of the replicating forms, with bands of molecular weight of $5 \times 10^{6}$ $\mathrm{D}$ and $4.6 \times 10^{6} \mathrm{D}$. These electrophoretic patterns are different from those obtained in our investigation, in which three bands of dsRNA (4.2, $10^{16}$ and $1.5 \times 10^{6} \mathrm{D}$ ) were obtained for the virus associated with thickening of the cladodes of prickly pear. This all suggests that this virus of prickly pear has perhaps not yet been reported for the crop. Amplification of the endogenous constitutive gene for GAPDH showed that all samples were free of inhibitors for the RT-PCR reaction, and that therefore this study was not dealing with TMV, genera of the family Potyviridae or species of the genus Potexvirus. The fact that the samples presented symptoms typical of those caused by virus, and that the presence of TMV, members of the family Potyviridae or species of Potexvirus was not detected, despite these viruses having been reported in prickly pear in Mexico, suggests that the virus associated with the syndrome of thickening and mosaic in prickly pear is from a different genus to those so far reported in prickly pear.

\section{CONCLUSIONS}

Through the analysis of double-stranded RNA, tests of mechanical transmission to indicator plants, electron microscopy and the molecular technique of RT-PCR used in this study, the presence of a phytopathogenic virus associated with thickening of prickly pear cladodes was demonstrated. However, this virus does not belong to the genera Tobamovirus, Potyvirus or Potexvirus, which are reported frequently in prickly pear. Thus, it is probable that this virus has yet to be reported for this crop.

\section{RESUMO}

Os sintomas de amarelecimento, mosaico, espessamento dos cladódios e proliferação e deformação dos frutos da pêra espinhosa, têm sido observados em Nopaltepec, Estado do México. Diante do problema, objetivou-se neste trabalho determinar a possível etiologia viral desses sintomas em amostras de 
pêra espinhosa que apresentavam a síndrome de espessamento dos cladódios. A análise de RNA de dupla fita (dsRNA) em tecidos da planta com os sintomas mencionados está relacionado com a presença de RNA viral. Em amostras procedentes de tecidos sintomáticos foram observadas partículas alongadas e flexíveis de 950-1,700 $\mathrm{nm}$ de comprimento em microscópio eletrônico de transmissão. O vírus foi transmitido mecanicamente a Nicotiana tabacum var. Xanthi, N. glutinosa, N. occidentalis, N. benthamiana, Chenopodium quinoa, C. amaranticolor e Datura stramonium. Os membros da família Potyviridae, das espécies do gênero Potexvirus e do TMV, em testes de RT-PCR, não estão relacionados com o vírus em estudo. Diante do resultado obtido, recomenda-se testálo com primers em outras espécies de virais.

Palavras-chave: dsRNA, partículas alongadas e flexíveis, pêra espinhosa, microscopia eletrônica de transmissão

\section{REFERENCES}

Abou Haidar, M. G.; Xu H.; Hefferon, K. L. (1998), Plant Virology Protocols. Methods in Molecular Biology, 81, 131-143.

Astier, S.; Albouy, J.; Maury, Y.; Robaglia, C.; Lecoq, H. (2006), Principles of plant virology, genome pathogenicity, virus ecology. First edition. Sciencie Publisher, 472p.

Attothom, S.; Weathers, L. G.; Gumpf, D. J. (1978), Identification and characterization of a potexvirus from California barrel cactus. Phytopathology, 68, 1401-1406.

Barbera, G. (1995), History, economic and agroecological importance. pp.1-11. In: G. Barbera, P. Inglese, E. B. Pimienta, and E. J. Arias (eds.). Agroecology, cultivation and uses of cactus pear. FAO, Roma, Italy, 280p.

Borrego, E. F. and Burgos, N. (1986), El Nopal. Universidad Autónoma Agraria Antonio Narro. Saltillo, Coahuila, México,7-85.

Brunt, A. A. K.; Cabtree, M. J.; Dallwitz, A. J.; Gibbs, J. W. (1996), Viruses of plant. Description and list from the (VIDE) data base (AL) international. CAB International. Cambridge, Massachussets, USA, 1484p.

Chen, J.; Chen, J.; Adams, M. J. (2001), A universal PCR primer to detect members of the Potyviridae and its use to examine the taxonomic status of several members of the family. Archives of Virology, 146, 757-766.

Colariccio, A.; Eiras, M.; Vicente, M.; Chagas, C. M.; Harakava, R. (1996), Caracterização parcial de umisolado do vírus do mosaico do pepino de $\mathrm{Musa}$ sp. "nanicão". Fitopatologia Brasileira, 21, 268274.

Conti, M.; Gallitelli, D.; Lisa, V.; Lovisolo, O.; Martelli, G. P.; Ragozzino, A.; Rana, G.L.; Vovlas, C. (2001), Principales virus de las plantas hortícolas. Ediciones Mundi Prensa. Barcelona, España, 206p.

Curtis, J. R. (1977), The development of commercial prickly pear farming in the Santa Clara Valley, California. Cactus and Succulent Journal, 47, 35-37.

De La Torre, R.; Salazar Segura, M.; Ruiz, Medrano, R. (2007), Ocurrencia de un Tobamovirus asociado con manchas anulares amarillas en nopal tunero en México. Agrociencia, 41, 763-773.

Dodds, J. A.; Morris, T. J.; Jordan, R. L. (1984), Plant Viral Double-Stranded RNA. Annual Review of Phytopathology, 22, 151-168.

Felker, P.; Bunch, R.; Russo, G.; Tani, J. A. (2009), Progreso en la identificación del agente causal de Engrosamiento del cladodio o macho. In: Producción y aprovechamiento del Nopal, 467p.

Fernández-Herrera, E. (2011), Genes de defensa, actividad enzimática y contenido de capsidiol en chile CM-334 resistente a Phytophthora capsici e infectado por Nacobbus aberrans. PhD Thesis, Colegio de Postgraduados, Montecillo, Edo. de México, México, 84p.

Giri, L. and Chessin, M. (1975), A severe strain of Tobacco mosaic virus from cactus. Phytopathology, 65, 824-825.

Gutiérrez, V. C.; Ruiz, R.; Piedra, E.; De La Torre, R. (2004), Caracterización de una variante del virus mosaico del pepino (CMV) asociada con los síntomas de moteado amarillo de la azucena (Hippeastrum x hybridum Leopoldii) en México. Agrociencia, 38, 343-354. 
Hausbeck, M. K. and Gildow, F. E. (1991), First report of Tomato spotted wilt virus on Thanksgiving cactus. Plant Disease, 75, 215.

Himmel, P. T. (2003), Tobacco mosaic virus. Compendium of pepper diseases. APS Press, Page. 38-39.

ICTV (International Committee on Taxonomy of viruses). (2005), Virus Taxonomy. C. M. Fauquet, M. A. Mayo, J. Maniloff, U. Desselberger, L. A. Ball (eds). pp. 821 and 1091. Elsevier Academic Press. San Diego, California, USA, 1259p.

Kraus, J.; Cleveland, S.; Putnam, M. L.; Keller, K. E.; Martin, R. R.; Tzanetakis, I. E. (2010), A new Potyvirus sp. infects verbena exhibiting leaf mottling symptoms. Plant Disease, 94, 1132-1136.

Lastra, J. R.; Gaskin, D.; De Uzcátegui, R. C. (1976), Virus X del Cactus en Venezuela. Agronomía Tropical, 26, 303-310.

Milbrath, M. G. and Nelson, M. R. (1972), Isolation and characterization of a virus from saguaro cactus. Phytopathology, 62, 739-742.

Nerd, A. and Mizrahi, Y. (1993), Modern cultivation of prickly pear in Israel: fertigation. Acta Horticulturae, 349, 235-237.

SIAP (Servicio de Información Agroalimentaria y Pesquera), (2009), Producción Agrícola, cíclicos perennes de nopal. www.siap.gob.mx. (date accessed: agosto 2011).
Sudzuki, F.; Muñoz, C.; Berger, H. (1993), El Cultivo de la Tuna (Cactus pear). Universidad de Chile, Santiago. Facultad de Ciencias Agrarias y Forestales, 88p.

Valenzuela-Herrera, V.; Redondo-Juárez, E.; Bujanos-Muñiz, R. (2003), Detección de virus por serología y plantas indicadoras en el tubérculosemilla y plantas de cultivo de meristemos en papa (Solanum tuberosum L.) var. Alfa. Revista Mexicana de Fitopatología, 21, 176-180.

Valverde, R. A.; Dodds, J. A.; Heick, J. A. (1986), Double-stranded ribonucleic acid from plants infected with viruses having elongated particles and undivided genomes. Phytopathology, 76, 459465 .

Van der Vlugt, R. A. A. and Berendsen, M. (2002), Development of a general potexvirus detection method. European Journal of Plant Pathology, 108, 367-371.

Wessels, A. B. (1988), Spineless Prickly Pear. First Perskor Publishers, Johannesburg. Cape Town, South Africa. Luxor publications, 168-169.

Zerbini, F. M. and Zambolim, E. M. (1999), A familia Potyviridae. Revisão Anual de Patologia de Plantas, 7, 1-66. 